\title{
Do rany przyłóż
}

Dlaczego „rana”? Słowo mocne, dotkliwe. Wydawać by się mogło, że w przestrzeni marketingowej nie sposób wylansować produktu o tej nazwie, od pierwszego kontaktu nie budzi ono dobrych skojarzeń, odstręcza, wywołuje lęk lub obrzydzenie, wymaga znieczulenia i zasłony, balsamu i plastra.

Rana boli i przeszkadza, zasklepia się lub jątrzy, raz lepiej, innym razem gorzej się goi, zostawia blizny. Jest uszkodzeniem zewnętrznych tkanek ciała, które wzywa organizm do walki o powrót do stanu równowagi, mobilizuje do ponawianych prób odzyskiwania stałości fizycznej i psychicznej. Ranę trudno zbyć obojętnością, towarzyszące jej cierpienie zmienia, dezintegruje, lecz zmusza, by utraconą całość budować na nowo.

Dotkliwość rany otwiera miejsce na wiele opowieści. O nienaruszalności granic, niemożliwej kompletności i braku, cierpieniu i bezsilności, krzywdzie i okrucieństwie, ciele i samotności, chorobie i śmierci, ale także o mocy istnienia, które w zagrożeniu uświadamia sobie swoją wartość. Nieunikniona konfrontacja ze światem, niemożliwa bez dyskomfortu i gwałtu, odsłania zarówno negatywność, jak i tożsamościowy sens rany.

Profil czasopisma, którego pierwszy numer prezentujemy, wpisuje się $\mathrm{w}$ badania nad tropami egzystencji $\mathrm{w}$ literaturze, istotne jest dla niego pytanie o jej jednostkowy wymiar, rozpoznawany $\mathrm{w}$ zapisach doświadczenia i podmiotowych projekcjach tożsamości. Pojęcie rany, kluczowe dla naszej propozycji lektury i zarazem jej „znak firmowy”, stanowi specyficzny sposób spojrzenia na literaturę i kulturę, a także - co równie ważne - relację człowieka z szeroko rozumianym środowiskiem. Widząc $w$ "ranie" potencjał daleko wykraczający poza treść i tematykę czytanych i pisanych 
tekstów, wiążemy ją z ważnymi obecnie nurtami humanistyki, zwłaszcza humanistyką zaangażowaną, opartą na empatii, trosce i wrażliwości.

Naszym celem jest prowadzenie badań nad literaturą, które $\mathrm{w}$ ramach refleksji humanistycznej uwzględniałyby przede wszystkim tożsamościowe znaczenie ran, skaz i blizn, rozumianych tak dosłownie, jak i symbolicznie. Zależy nam na stworzeniu naukowej przestrzeni dla publikacji o profilu, który dowartościowałby rozważania o egzystencjalnym wymiarze literatury. Ranę postrzegamy jako efekt konkretnej sytuacji życiowej i jednostkowej traumy, ale, co ważniejsze, zauważamy, że doświadczone cierpienie utrwalają i blizna, i pismo. Teksty, które piszemy i do których pisania zachęcamy, działają podwójnie: próbują odszyfrować sens rany, ale i zaszyfrować ją we własnych słowach. Czytanie i pisanie/nadpisywanie na bliznach wydaje nam się praktyką ważną dla wszystkich uczestników literackiej wymiany. Pytamy zatem, po pierwsze, o znaczenie sytuacji granicznej podmiotu piszącego i ujawniamy jego „,czułe punkty”; po drugie jednak, docieramy do możliwości czytania cudzej rany jak własnej, z „widoku cudzego cierpienia" czerpiąc zysk tożsamościowy i wspólnotowy, dostrzegając wartość przeżycia i możliwość zmiany, metamorfozy siebie. Teksty literatury i kultury umożliwiają nam zobaczenie rany w piśmie, obcowanie z jej reprezentacją właśnie dzięki pismu, nasze praktyki badawcze z kolei pozwalają uchwycić akt pisania budowany na ranie - i ten podwójny, pozytywny sens ran chcemy uczynić sednem proponowanej refleksji.

„Rana" - niejednoznaczna i bogata w konotacje - pozwoli wybrzmieć różnorodnym zagadnieniom. Pierwszy numer czasopisma poświęcony został traumie, jej konstruowaniu i (nie)przepracowaniu, zdarzeniom historycznym i jednostkowym jako jej źródłom, literackim sygnałom i obrazom traumy oraz jej tożsamościowym konsekwencjom. Trauma jest szczególnym rodzajem zranienia, które trwa i rozwija się w czasie, a jego spóźniona czasowość, objawiająca się w powrotach i powtórzeniach, czyni z niej doświadczenie ze wszech miar wieloznaczne i trudno uchwytne. Mark Seltzer postrzega ją jako „rodzaj punktu przecięcia tego, co »psychospołeczne«. Sama niepewność, co do właściwego statusu traumatycznego zranienia czy jest ono psychiczne, czy fizyczne, prywatne czy publiczne, czy jest kwestia przedstawienia (fantazją), czy percepcji (zdarzeniem), stanowi na kilku poziomach sygnał owego bolesnego punktu przecięcia. Pojęcie traumy funkcjonuje zatem nie tylko jako swego rodzaju przełącznik między porządkiem cielesnym a psychicznym. 
To także punkt przełącznikowy między tym, co jednostkowe i zbiorowe, między prywatnym i publicznym porządkiem rzeczy"1. Artykuły zebrane w pierwszym numerze czasopisma do tak zakreślonej wieloznaczności traumy na różne sposoby próbują się zbliżyć.

Znaczna część przedstawionych tu szkiców w pierwotnej wersji prezentowana była na ogólnopolskiej konferencji naukowej Przeszłość (nie)miniona. Trauma - przemoc - tożsamość, zorganizowanej w maju 2019 roku na Wydziale Filologicznym Uniwersytetu Śląskiego w Katowicach z inicjatywy dwóch ówczesnych studentek - Martyny Dymon i Martyny Okrajni. Szerokie zainteresowanie tematyką sesji było jednym z impulsów realizacji pomysłu o powołaniu tak sprofilowanego czasopisma.

Jego problematyka, mimo że niełatwa (a może właśnie dlatego), jest stale obecna w humanistycznej refleksji, w ramach której poddawana jest dyskusjom i modyfikacjom. Zależy nam na tym, by mieć w tym namyśle istotny i własny udział. Chcemy, by nasze pismo miało przede wszystkim mocny charakter naukowy, ale pragniemy również, by stało się śladem naszego humanistycznego, egzystencjalnego zaangażowania w proces rozumienia ciężaru ran jako elementów budujących tożsamość jednostek i grup społecznych.

W przeszłości uwznioślano i sakralizowano rany. Autor Sułkowskiego wzywał - jak pamiętamy - do ich rozdrapywania, by ustrzec się przed błoną podłości - niepamięci i zobojętnienia. Różewiczowska „poezja jak otwarta rana” nie pozwala zapomnieć o bólu, skazuje na niezaleczony niepokój. „Książka musi rozdrapywać rany, a nawet je zadawać. Książka musi być zagrożeniem" - z właściwą sobie emfazą notuje Emil Cioran ${ }^{2}$. Etyczny imperatyw literatury nakazuje mierzyć się z raną istnienia, dotykać ran historii. Chwile szczęścia i dobrostanu doskonale radzą sobie bez słów, nie potrzebują opowieści, zdolne wypełnić się sobą bez reszty. Inaczej niż rana. Jej jątrząca dotkliwość domaga się świadectwa i pamięci, zmusza do poszukiwania/budowania sensu, wzywa do odpowiedzialności także w obliczu absurdu. Tożsamościowa narracja nie może się powieść bez odniesienia do zranień, humanistyczna możliwość poznania i terapii zależy najpewniej od znalezienia dla nich miejsca w opowieści. Terapeutyczny i etyczny sens literatury ma wszakże jeszcze inny wymiar: „Godziny przy piórze - one leczą rany, / One

${ }^{1}$ M. Seltzer: Kultura rany. Przeł. A. Rejniak-Majewska. W: Antologia studiów nad trauma. Red. P. Łysiak. Przeł. T. Bilczewski, K. Bojarska, J. Burzyński, A. Kowalcze-Pawlik, A. Rejniak-Majewska. Kraków 2015, s. 315.

${ }^{2}$ E. Cioran: Ćwiartowanie. Przeł. M. Falski. Warszawa 2016, s. 86. 
też wstrzymują od ran zadawania" ${ }^{\prime \prime}$. Piękna utopia Grochowiaka karmi nas obietnicą, że w literaturze odnajdziemy - choć tylko do pewnego stopnia skuteczny - balsam na rany świata.

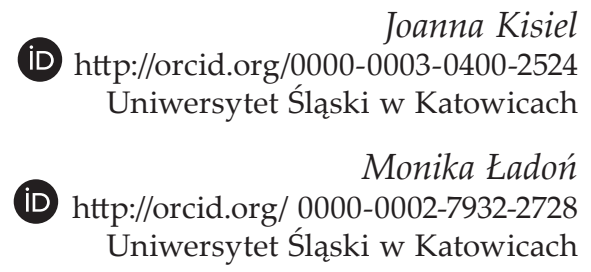

${ }^{3}$ S. Grochowiak: Ars poetica. W: Inem: Wiersze zebrane. Wybór, oprac. i red. B. Symber. T. 1. Wrocław 2017, s. 310. 